\title{
A FLEXIBLE STILETTE FOR REPLACING DAMAGED TRACHEAL TUBES
}

\author{
Brendan T. Finucane and Hilton L. KupshiK
}

IN 1880 WILL.IAM MACEWEN' introduced endotracheal anaesthesia. Since that time numerous instruments and devices have been added to our armamentarium to facilitate access to the airway. ${ }^{2}$ The most recent addition has been the fiberoptic laryngoscope. ${ }^{3}$ These sophisticated measures allow placement of a tracheal tube even in the most difficult circumstances.

An area of relative neglect commands attention when one is confronted with the problem of replacing a damaged or obstructed tracheal tube. The following case report illustrates the value of a flexible stilette to replace a damaged tube.

\section{CAse Report}

A 36-year-old-male weighing $68 \mathrm{~kg}$ presented for posterior cervical spinal fusion. He was involved in an automobile accident and sustained a cervical fracture which was unstable; otherwise he was in good general health. The plan of anaesthesia entailed awake blind nasal intubation or placement of the tracheal tube using fiberoptic laryngoscopy. Following sedation with a combination of Innovar and diazepam, the nasal mucosa and oropharynx were sprayed with cocaine. In addition a transtracheal injection of four $\mathrm{ml}$ of lidocaine two per cent was administered. A superior laryngeal nerve block was performed on each side with two $\mathrm{ml}$ of one per cent lidocaine. With some difficulty an $8.5 \mathrm{~mm}$ Portex nasotracheal tube was inserted blindly. Following intubation, the patient was instructed to move his feet, which indicated that he was neurologically intact. Immediately thereafter general anaesthesia was induced. There was considerable bleeding from the nose. In addition, it became apparent that there was a marked leakage of gases around the tracheal tube, which was unacceptable. The alternatives at this stage were to insert a

Brendan T. Finucane, M.D., F.R.C.P.(C), Chief, Department of Anesthesiology, Assistant Professor, Emory School of Medicine, and Hilton L. Kupshik, M.B., B.Ch., Grady Memorial Hospital, Department of Anesthesiology, Emory University School of Medicine, 69 Butler Street, S.E., Atlanta, Georgia 30303, U.S.A.

Canad. Anaesth. Soc. J., vol. 25, no. 2, March 1978 pack in the oropharynx or to change the tracheal tube. The latter course was taken

The whole object of performing an awake intubation was to protect the patient from damage to the cervical spinal cord. Further attempts at laryngoscopy with the patient under general anaesthesia would be considered hazardous and would defeat the whole object of the method employed. To avoid further manipulation of the airway the following technique was used.

\section{TECHNIQUe}

A Sorenson central venous pressure line had been introduced earlier. This catheter is enveloped in a protective conduit (see Figure 1) which is usually discarded. This is a hollow piece of tubing which is quite flexible and one end is sealed and smooth. It is about $63 \mathrm{~cm}$ in length and $4 \mathrm{~mm}$ external diameter.

The smooth blind end of this flexible stilette was advanced through the lumen of the damaged tracheal tube well beyond the tip. The latter was then removed in retrograde fashion over the flexible stilette and replaced with a clean sterile nasotracheal tube without difficulty. Following removal of the stilette breath sounds were audible bilaterally. The remainder of the procedure was uneventful.

\section{Discussion}

This technique has been used in a number of situations requiring a change of tracheal tube. Damage to the cuff of tracheal tubes is a common accompaniment of nasal intubation when using a Magill forceps. In the more difficult oral intubations the sharp edges of teeth may sometimes shear the cuff.

Most experience with this technique has been gained in the operating room in patients under general anaesthesia with full muscle relaxation. However, this technique has been used in the Intensive Care Units in awake patients with equal success.

In a similar fashion this stilet te has been used to intubate the left main stem brochus when it is necessary to isolate the left lung. The latter is first 153 


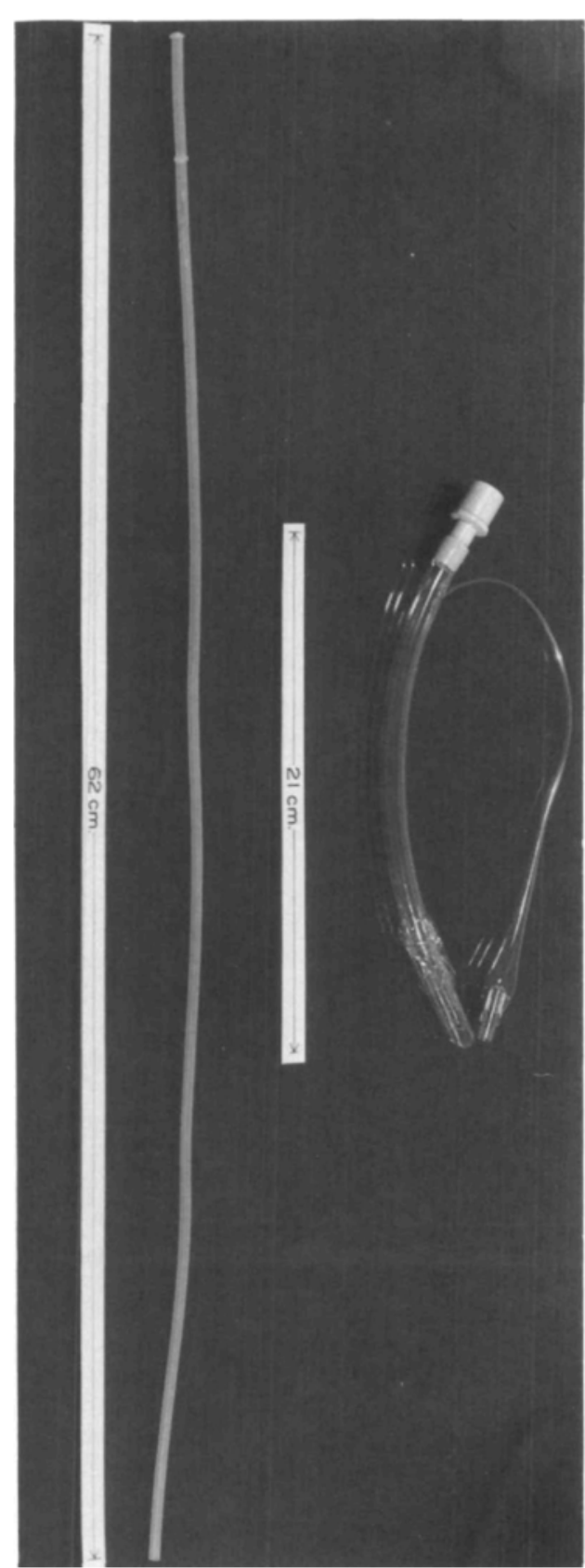

Figure 1 isolated with a rigid bronchoscope, then the stilette is introduced as far as the left main stem and the bronchoscope is withdrawn. A tracheal tube is then easily inserted over the stilette.

A fiberoptic laryngoscope may be utilized in this situation if necessary. However, it is felt that the technique described above is a simple and more economical alternative.

\section{SUMMARY}

A simple method to facilitate exchange of a damaged tracheal tube is described. The technique entails the passage of a flexible stilette $4 \mathrm{~mm}$ in diameter through a damaged tracheal tube, which is then removed and replaced with a new sterile one passed over the stilette. The technique can be used in conscious or unconscious patients.

A case report is included to illustrate application of the technique.

\section{RÉSUMÉ}

Les auteurs présentent une technique simple facilitant le changement de tubes endotrachéaux. Cette méthode est particulièrement utile dans les cas d'intubation difficile et a été utilisée tant chez des malades conscients qu'inconscients.

Un stylet flexible (l'enveloppe extérieure du cathéter à pression veineuse de Sorenson) de 63 $\mathrm{cm}$ de longueur et de $4 \mathrm{~mm}$ de diamètre est d'abord inséré dans le tube à changer. Ce demier est retiré en laissant le stylet en position dans la trachée. Enfin, le nouveau tube endotrachéal est introduit en utilisant le stylet comme guide.

Un cas typique est rapporté.

\section{REFERENCES}

I. Gie.tespif, N.A. Endotracheal anesthesia. Second Edition, Madison, University of Wisconsin Press. p. 9 (1950).

2. SAlEm, M.R., Mathrubhuthan, M.. \& Bennet. E.J. Difficult intubation. N.E.J.M. 295: 16, 879-881 (1976).

3. MURPHY, P. A fiber optic endoscope used for nasal intubation. Anaesthesia, 22: 489-491 (1967). 